\title{
OVERALL RAILWAY INFRASTRUCTURE EFFECTIVENESS AS A QUALITY FACTOR FOR SERBIA RAILWAYS
}

\author{
Ivica Nikolić, Slavko Arsovski, Milan Erić, Sladjana Vujičić, Goran Manojlović, Jelena Jovanović
}

Preliminary notes

This paper analyzed the possibility of monitoring the parameter OEE for "Serbia Railways" JSC. Transpatternation of indicators and of pattern for OEE in order to make them appropriate for use in railway infrastructure is known as Overall Railway Infrastructure Effectiveness - ORIE. This work represented a model for calculation of ORIE. It is proven that the program, which works at Swedish railways, can be adapted in order to make it functional for infrastructure of "Serbia Railways" JSC. Also, this work includes conducted adaptation and proposal of ORIE patterns which will satisfy specific needs for calculation of values for "Serbia Railways" JSC. Using the case study, it is calculated for three railway relations in Section for infrastructure of Požarevac that the value of ORIE based on real data differs in rang from $47,95 \%$ to $60,71 \%$.

Keywords: effectiveness; infrastructure; quality; railways

Ukupna efektivnost željezničke infrastrukture kao faktor kvalitete na željeznici Srbije

Prethodno priopćenje

U radu je analizirana mogućnost praćenja parametra OEE kod infrastrukture "Železnice Srbije" ad. Transformacija indikatora i obrasca za OEE u odgovarajući koji se koristi za željezničku infrastrukturu zove se ukupna efektivnost željezničke infrastrukture (overall railway infrastructure effectiveness - ORIE). U radu je predstavljen model za izračun ukupne efektivnost željezničke infrastrukture (ORIE). Dokazano je da se program, koji funkcionira na Švedskim željeznicama, može prilagoditi da funkcionira i na infrastrukturi "Železnice Srbije" ad. U radu je izvršena prilagodba i prijedlog obrazaca ORIE koji će zadovoljiti specifične potrebe za izračun vrijednosti za "Železnice Srbije" ad. Studijom slučaja izračunato je za tri relacije pruga u Sekciji za infrastrukturu čvora Požarevac, da se vrijednost ORIE utemeljena na realnim podacima razlikuje od 47,95 \% do 60,71\%.

Ključne riječi: djelotvornost; infrastruktura; kvaliteta; željeznica

\section{Introduction}

Serbia Railways conducted categorization according to applicable Regulation for railways categorization. All railways in network are divided into two main classes: magisterial railways and others. First group includes two subgroups, main and assistive, while the second group includes $1^{\text {st }}$ and $2^{\text {nd }}$ class railways. The backbone of railway network in Serbia is Corridor X (Salzburg Ljubljana - Zagreb) - (ک̌id - Belgrade - Niš - Preševo) (Veles - Skopje - Thessaloniki) with branches over Subotica to Hungary and Dimitrovgrad to Bulgarian border, with total length of $872 \mathrm{~km}$. Its improvement is strategically important for Serbia and EU.

Magisterial railways are generally projected for maximum speed of $120 \mathrm{~km} / \mathrm{h}$. The railway Belgrade Vrbnica (- Bar) represents an exception. Because of complex terrain and many sharp bends, it is projected for speed $80 \div 100 \mathrm{~km} / \mathrm{h}$. Also, for most complex sections of railways Niš - Preševo and Niš - Dimitrovgrad this is mostly implemented. Currently allowed trains speeds are mostly less than projected. The speed of $100 \mathrm{~km} / \mathrm{h}$ is maximal for all railways in practice, except in repaired left track for railway (Belgrade) - Nova Pazova - Šid.

The average speed limit on the rails of Corridor $\mathrm{X}$ is now reduced to $82 \mathrm{~km} / \mathrm{h}$, and the theoretical value in practice corresponds to the maximum average speed of trains of more than $60 \mathrm{~km} / \mathrm{h}$. Difference between speed limit and actual speed and theoretical and projected speed is usually known as speed limitation. The projected speed is a speed, which cannot be developed at railway regarding vertical and horizontal geometry of railway. The actual speed is a speed at which trains actually can drive.
During the last decade of the $20^{\text {th }}$ century, there were no investments in railway infrastructure and rolling stock, while the regular maintenance of railway infrastructure was minimal. As consequences, there are bad conditions of infrastructural objects, high percentage of defective railway rolling stock and low quality of transport services. Performances of railway network infrastructure and quality of railway rolling stock need to be at much higher level in order to satisfy the needs of modern traffic market. This is the only way to make number of passengers and cargo traffic intensity larger than current.

\section{The aim of the work}

There is a need for continuous improvements in area of railway infrastructure maintenance. Maintenance not only ensures the safety of passengers and goods, but creates additional value in the business process [8]. It is very important for the "Serbia Railways" JSC, to maintain the existing infrastructure through effective and efficient maintenance in order to sustain high capacity utilization with the highest possible levels of security, and accuracy increasing. The main aim of the research work is to identify and study existing operations and indicators for railway infrastructure maintenance, including their implementation in long and short perspective, to analyze their usefulness for work and planning of railway infrastructure maintenance.

Also, the aim of the work is to propose additional indicators for evaluation of effectivity of railway infrastructure for "Serbia Railways". Transpatternation of indicators and pattern for OEE in order to make them appropriate for use in railway infrastructure is known as Overall Railway Infrastructure Effectiveness - ORIE. 
The aim of this study is to develop an approach for measuring the overall railway infrastructure effectiveness - ORIE for "Serbia Railways" and to test this approach through a case study.

\section{Literature review}

Infrastructure maintenance represents one of the largest expenses of railway in order to improve efficiency and reliability of equipment. The measurement of railway infrastructure gives a basis for improvement. The succesful realization of railway infrastructure and its use provides improvement and reduction of costs and offers reliable and sustainable system. Generally, almost all networks need to give more than existing infrastructure. Using implementation of efficient program for maintenance of railway infrastructure, costs and economies due to unexpected faults can be controlled [1]. The interruption of railway infrastructure in only one moment can make ripples through entire railway system. In other words, the interruption of any part of infrastructure can reduce the traffice to $50 \%$ [2]. This is why it is important to maintain the existing condition of infrastructure, using effective and efficient maintenance in order to retain high level of usefulness of capacities, with the highest possible levels of security and accuracy. Also, there is a need for continuous improvements in the area of maintenance of railway infrastructure.

Ahren and Parida [3] suggested a model for calculation of OEE for maintenance of railway infrastructure, known as overall railway infrastructure effectiveness - ORIE. In their work, they noted that: "ORIE model is focused on movable times used for traffic operations in which the enterprise works. In other words, it is focused on reserved railways of trains according to timetable". Main indicators of ORIE model are the same for ordinary OEE and they can be multiplied in the same way, but their definitions differ. Cases of study are conducted at three sections of railway. They provided similar ORIE results, which are significantly larger than industrial OEE. Such high ORIE results are needed for an accurate system of railway traffic. The study showed that ORIE needs to be calculated monthly. Obtained results for ORIE were in rang from $89,7 \%$ to $100 \%$. It is showed that ORIE can be used as a key perpatternance indicator for managers of railway infrastructure. Also, ORIE can provide a significant contribution for infrastructure managers and support in decision making process.

Most of European managers for railway infrastructure make efforts to develop and implement tools needed for professional maintenance. Countries such as Austria, France, Germany and Holland have developed computer models for estimation of life cycle costs. They are implemented for decisions related to infrastructure maintenance. Decisions regarding construction and management have a longterm influence. If preventive maintenance is systematically reduced, resources can easily become outdated which can create significantly high maintenance costs [4]. Analysis and planning of resources maintenance for systematic analysis and optimization of budget, minimising of total costs and warant for railway stock quality are needed for a longtime period.

\section{Methodology \\ 4.1 Scope and purpose of research}

The main subject of this research is to analyze the possibility of tracking parameter of OEE in railway infrastructure. The known Transpatternation of indicators and pattern for OEE in order to make them appropriate for use in railway infrastructure is known as overall railway infrastructure effectiveness - ORIE. Also, the aim of this work is to propose indicators for measurement of effectiveness of railway infrastructure for "Serbia Railway" JSC, in order to achieve quality improvement.

\subsection{The importance of research}

Theoretical importance of research can be reflected in better understanding and greater acceptance of the use of patterns of ORIE, which can be used for calculating of overall effectiveness of railway infrastructure by infrastructure managers in "Serbia Railways". Practical importance can be reflected in measurement of effectivenes of railway infrastructure, which also influences productivity and quality.

\subsection{Case study}

Modification of pattern for calculating of ORIE value has been conducted. It has been adapted for functioning in Serbia Railways. The case study for three sections of the railway has been prepatterned on a monthly basis for year 2011.

\subsection{Data collection techniques}

Data for calculation have been collected by Organizational entity for traffic businesses (OE for TB), Organizational entity for railway maintenance (OE for RM) and Organizational entity for electric-technic businesses (OE for ETB). All three units work in pattern of Section for infrastructure of the Pozarevac knot. They are in charge of infrastructure maintenance. This infrastructure includes all three railway sections taken as a sample in the case study.

\subsection{Data processing plan}

Collected data are used in the pattern for calculation of ORIE value which is modified and adapted for "Serbia Railways" JSC and presented in the case study.

\subsection{Research hypotheses}

H0: Pattern ORIE improves the possibility of monitoring overall effectiveness of railway infrastructure for Serbia Railways.

H1: ORIE can be used by managers of railway infrastructure as a key perpatternance indicator.

$\mathrm{H} 2$ : Railway infrastructure managers have need and demands to calculate overall effectiveness of railway infrastructure.

H3: ORIE offers important entrances for infrastructure managers who demand more quality in decision making processes. 


\section{Overall Railway Infrastructure Effectiveness - ORIE}

ORIE calculation is similar to OEE (overall effectiveness of equipment) and calculations used for production and manufaturing industry. Obtained ORIE numbers show high values regarding industrial OEE. The concept of ORIE has the aim to discover how well railway infrastructure system can deliver arranged services. It means that high ORIE marks are needed for an accurate traffic $[3,8]$. Suggested ORIE calculation is tested according to real data for three sections of railways in Section for infrastructure of the Pozarevac knot. The value of ORIE is based on real data and it differs from $47,95 \%$ to $60,71 \%$.

ORIE calculation is conducted by multiplying availability of infrastructure $(A)$, usefulness of performances for infrastructure $(P)$ and quality of infrastructure $(K)$, see Eq. (1).

$$
\text { ORIE }=A \cdot P \cdot K
$$

Infrastructure availability $(A)$ is the first variable that should be defined. The actual allocated uptime (UT) for specific railway should be calculated. It should be kept in mind if the railway is considered for day traffic or permanently during $24 \mathrm{~h}$. Downtime due to the infrastructure fault (TDIF) is the first loss of time and it is related to a time when infrastructure is not available for traffic. Also, it calculates the time which is needed for reparation and waiting time. The second loss of time presents the downtime due to overdue maintenance $(T D O M)$ and it presents the time needed for planned maintenance activities.

Infrastructure availability $(A)$ is the function of allocated up time (UT) and down time due to infrastructure failures (TDIF) and down time due to overdue maintenance (TDOM). See Eq. (2).

$A=\frac{U T-(T D I F+T D O M)}{U T}$,

where: $U T$ - allocated UpTime; TDIF - DownTime due to Infrastructure Failures; TDOM - DownTime due to Overdue Maintenance.

Infrastructure performances $(P)$ represent the second variable that needs to be identified. It is needed to calculate the total train operating time (TTOT) according to timetable and then third and second loss of time. During calculating the losses of time, it is needed to consider planned and unplanned speed reduction. Speed reduction planned by timetable is considered as planned speed reduction (limited speed) and all losses over that time present delay not caused by needed maintenance (TDNMR). The fourth loss presents train delay because of unplanned speed reduction (TDSR), or slow runs which are introduced as needed and where maintenance is needed in order to remove them.

Infrastructure performances $(P)$ present the function of planned total time of train operation (TTOT), train delay not caused by maintenance $(T D N M R)$ and train delay due to speed reduction or slow runs (TDSR). See Eq. (3).

$$
P=\frac{T T O T}{T T O T+T D N M R+T D S R}
$$

where: TTOT - scheduled Total Train Operating Time; TDNMR - Train Delays due to No Maintenance Required; $T D S R$ - Train Delays due to Speed Reductions.

Infrastructure quality $(K)$ presents the third variable. Banverket uses two values for quality, $K$ and $Q$. These values describe quality regarding vertical and horizontal balancing. Measurements are conducted by vechicles for railway measuring known as STRIX. For ORIE calculations, the value of $Q$ is used. Large dynamical forces can damage infrastructure and present potential risk for derailment. The calculation of ORIE losses in quality can be conducted using $K$ or $Q$ values [3, 8].

For calculation of ORIE value, Banverket used the value $Q$, which presents the real $Q$-value $\left(Q_{\text {val }}\right)$ and defined limits of $Q\left(Q_{\text {lim }}\right)$. See Eq. (4).

$$
\begin{aligned}
& Q=\frac{Q_{\mathrm{val}}}{Q_{\mathrm{lim}}} \text { if } Q_{\mathrm{val}}<Q_{\mathrm{lim}}, \\
& Q=1 \text { if } Q \geq Q_{\mathrm{lim}},
\end{aligned}
$$

where: $Q_{\text {val }}$ - measured $Q$ value; $Q_{\text {lim }}$ - stated $Q$ limit.

"Serbia Railways" JSC investigates and analyzes geometry of condition of track using measuring vechicle EM-80 L. Special devices are used for defining the tranquility of moving according to registered vertical and horizontal acceleration. Results can be obtained in form of diagrams (graphics) and numerical reports. Numerical reports include data on condition of rail according to computer analysis. Continuous investigating on geometric condition of railways of third and fourth category is measured once a year (in spring or summer) [9]. According to that, for "Serbia Railways" JPC, the calculation for ORIE values will be adapted to $K$ value.

Infrastructure quality $(K)$ is the relationship between total rail section length with permitted deviations, without mistakes $B$ and $C,(\Sigma l)$ and total length of measured rail section length $(L)$. Mistakes in geometry of track are classified as $B$-mistakes or $C$-mistakes. $B$-mistakes are those which need plans for their removal - preventive maintenance. $C$-mistakes are those above exploitation limits and which demand urgent removal - corrective maintenance or speed reduction. This index is used for obtaining a common picture about condition of railway. It can be calculated according to the following pattern - Eq. (6), where:

$K=\frac{\Sigma l}{L} \cdot 100 \%$,

where: $\Sigma l$ - length of measured track without $B$ and $C$ istakes; $L$ - total length of measured track.

\section{Case study}

A part of the infrastructure of "Serbian Railways" was analysed for this case study. In other words, the Section for the infrastructure of the Požarevac knot, for 
three crossed rail sections in Mala Krsna station was analysed. First section is placed on relation Belgrade Mala Krsna, with length of $79 \mathrm{~km}$, with 20 distributed stations. The rail works permanently during $24 \mathrm{~h}$ for mixed transport of passenger and freight trains. The average driving time is 111 minutes. The second section is Mala Krsna - Majdanpek, with length of 109,2 km. This section is also intended for passenger and freight trains. This section is daily administered by 3 passenger and 22 freight trains. The average driving time is 211 minutes, while the rail permanently operates during $24 \mathrm{~h}$. The third section is on relation Smederevo - Mala Krsna, with length of $11,3 \mathrm{~km}$. This rail connects Smederevo port with
Smederevo steel mill and railway station Mala Krsna. It operates with 24 passenger and 9 freight trains on daily basis. The average driving time is 23 minutes while the rail operates during $24 \mathrm{~h}$.

Considering that all three rails operate constantly, allocated working time for all three relations will be calculated for $22 \mathrm{~h}$. If the rail is used for traffic during day and night, time needed for preventive maintenance should be two hours. In other words, planned working time is 22 h. Rail categories, planned working time, number of freight and passenger trains, average driving time are presented in Tab. 1.

Table 1 Input data for three rail sections for 2011

\begin{tabular}{|l|c|c|c|}
\hline \multicolumn{1}{|c|}{ Section } & Belgrade - Mala Krsna & Mala Krsna - Majdanpek & Smederevo - Mala Krsna \\
\hline Section class & III & IV & IV \\
\hline Allocated uptime & $22 \mathrm{~h}$ & $22 \mathrm{~h}$ & $22 \mathrm{~h}$ \\
\hline Length of the railways & $79 \mathrm{~km}$ & $109,2 \mathrm{~km}$ & $11,3 \mathrm{~km}$ \\
\hline No. of passenger trains / week & 33 & 162 & 170 \\
\hline No. of freight trains / week & 104 & 32 & 76 \\
\hline Estimated running time / train & $111 \mathrm{~min}$ & $211 \mathrm{~min}$ & $23 \mathrm{~min}$ \\
\hline
\end{tabular}

Presented input data for three rail sections are taken from Operative department which includes: Organizational units for traffic businesses (OU for TB Pozarevac), and Organizational unit for rail maintenance Pozarevac (OU FRM Požarevac) wich operate in Section for infrastructure of Pozarevac knot in Direction for infrastructure of "Serbia Railway" JSC.

Unplanned downtime due to fault in equipment shows the time when railway infrastructure was not able to be used for train traffic. The total time needed for infrastructure enabling presents the time of waiting and repair. Infrastructure maintenance for "Serbian Railways" is conducted by Department of Construction Business and the Department of Electro Technical Business.
If more trains are delayed due to the same fault in infrastructure, the unavailability of infrastructure cannot extend recorded train delay. This train has the longest delay for specific infrastructure failure. When the train with the longest time of waiting starts to move, the infrastructure is operative for traffic. Time of repairement is not a valid measure for infrastructure downtime. In other words, the traffic can operate although the maintenance is performed at the same time [3].

The total number of faults in devices by ETB is presented in Tab. 2. In order to calculate ORIE values, only faults which caused infrastructure failure were taken in consideration. In other words, those are failures because of trains being late.

Table 2 Total number of faults in devices for year 2011

\begin{tabular}{|c|c|c|c|c|c|c|}
\hline Failure report - ETB & ETB & FRM & TT & ACCIDENT & OTHER & $\sum$ \\
\hline Belgrade - Mala Krsna & 1033 & 718 & 172 & 6 & 198 & 2127 \\
\hline Mala Krsna - Majdanpek & 82 & 8 & 1 & 1 & 31 & 123 \\
\hline Smederevo - Mala Krsna & 230 & 72 & 1 & 8 & 8 & 319 \\
\hline$\sum$ & 1345 & 798 & 174 & 15 & 237 & 2569 \\
\hline
\end{tabular}

Delays due to infrastructure failures and interventions by OU FRM Pozarevac are presented in Tab. 3. In order to calculate ORIE values, only failures which caused infrastructure delays were taken in consideration. In other words, those are failures because the trains were late.

Table 3 Total number of interventions by FRM for year 2011

\begin{tabular}{|c|c|c|}
\hline Failure report - FRM & Number & Minute \\
\hline Belgrade - Mala Krsna & 6 & 754 \\
\hline Mala Krsna - Majdanpek & 36 & 4495 \\
\hline Smederevo - Mala Krsna & 1 & 123 \\
\hline$\sum$ & 43 & 5372 \\
\hline
\end{tabular}

Rails in the track may have the following errors: fractures, cracks and damages. Rail fractures - splitting of rail into two parts or when metal part which creates chamfer longer than $50 \mathrm{~mm}$ and deeper than $10 \mathrm{~mm}$ reaches the surface. Cracks are one or more interruptions of any orientation, visible or nonvisible, on any part of the rail, which can create a brakedown, after a certain time period. Damaged rail is every rail without fractures or cracks, but it contains other surface faults [11].

Decreased speed is a speed lower than maximum allowed rail speed or limited speed. This speed is introduced because of works or delays on some part of rail, object, plant etc. Slow driving is considered as driving at decreased speed. Review of slow drives for three rail sections for year 2011 is taken from OU FRM Požarevac $[13,14]$ and OU for TB Požarevac $[15,16]$ and is presented in table 4. Within infrastructure section for Požarevac knot, two reviews of slow drives were conducted during 2011. Records are made for: rail number, slow driving place (from $\mathrm{km}$ to $\mathrm{km}$ ), slow drive length, difference between regular and decreased speed and date of introduction of slow driving (reduced speed). Total number of slow drives for all three rail sections included in study from year 2011 was 39 until May, in the length of $110265 \mathrm{~m}$. For the period May- 
December, a total of 36 slow drives were conducted, in length of $84046 \mathrm{~m}$. Slow drives which increased to limited speed were not included in the study because they were included in timetable. Slow drives in Section for infrastructure of the Požarevac knot were introduced because of the following: poor track geometry, rotten sleepers, rails battered, worn-out elements of superstructure, rotten crossover lumber, rotting bridge lumber and more.

In order to increase perfomances requirements, infrastructure managers are often faced with old resources, undone maintenance and construction work and unrealized improvement in capacities, new technologies, etc.

Table 4 Review of slow drives for three rail sections for year 2011

\begin{tabular}{|c|c|c|c|}
\hline Slow drive - Reduced speed - TDSR & Belgrade - Mala Krsna & Mala Krsna - Majdanpek & Smederevo - Mala Krsna \\
\hline Section class & III & IV & IV \\
\hline Number of railway & 4 & 36 & 54 \\
\hline Number of slow runs the length of the I to IV month & $15 / 46627 \mathrm{~m}$ & $22 / 64396 \mathrm{~m}$ & $2 / 242$ \\
\hline Number of slow runs the length of V to XII month & $14 / 24699 \mathrm{~m}$ & $20 / 59105 \mathrm{~m}$ & $2 / 242$ \\
\hline Average delays per train from the I to the IV month & $27,92 \mathrm{~min}$ & $64,25 \mathrm{~min}$ & $2 \mathrm{~min}$ \\
\hline Average delays per train from V to XII month & $23,67 \mathrm{~min}$ & $69,29 \mathrm{~min}$ & $2 \mathrm{~min}$ \\
\hline $\begin{array}{l}\text { Allowed extension of time rolling stock in the } \\
\text { timetable for slow runs }\end{array}$ & $25 \mathrm{~min}$ & $39 \min$ & $2 \mathrm{~min}$ \\
\hline
\end{tabular}

Table 5 Delays due to delayed maintenance for three rail sections in year 2011

\begin{tabular}{|l|c|c|c|}
\hline \multicolumn{1}{|c|}{ Delayed maintenance - TDOM } & Belgrade - Mala Krsna & Mala Krsna - Majdanpek & Smederevo - Mala Krsna \\
\hline Section class & III & 36 \\
\hline Number of railway & 4 & 9 & 54 \\
\hline Total delayed maintenance & 50 & $4830 \mathrm{~min}$ \\
\hline The length of the delayed maintenance & $13175 \mathrm{~min}$ & $293 \mathrm{~min}$ \\
\hline $\begin{array}{l}\text { Total rolling stock time delays due to delayed } \\
\text { maintenance }\end{array}$ & $66 \mathrm{~min}$ & 354 min \\
\hline
\end{tabular}

Tab. 5 presented delays due to lack of maintenance related to rails closing. It is important to note that rail Beograd - Mala Krsna included largest number of closings and lowest number of train delays. Delayed maintenance was conducted in intervals when trains do not drive in order to avoid failures in train drives due to delayed maintenance.

Quality infrastructure rate $(K)$ is calculated according to analysis of data obtained by recording of rail condition, using device EM 80L, [18]. Data are obtained from OU
FRM Požarevac and presented in Tab. 6. Summary report about the rail condition presents the rail length, regarding observed part of rail with specific length $(1 \mathrm{~km})$ with exceeded limit values of one or more parameters for rail category. Data are presented by parameters for each subgroup (A, B and C) including number of registered mistakes by each parameter and their total length. The sum included total lengths with exceeding within observed rail length $(1 \mathrm{~km})$. Presented data are used for the estimation of rail condition.

\begin{tabular}{|l|c|c|c|}
\hline \multicolumn{1}{|c|}{ Table 6 Infrastructure quality for three rail sections for year 2011 } \\
\hline Number of railway & Belgrade - Mala Krsna & Mala Krsna - Majdanpek & Smederevo - Mala Krsna \\
\hline Section class & 4 & 36 & 54 \\
\hline Total length of measured track $-L$ & III & IV & IV \\
\hline Number of mistakes $-B$ & $35732 \mathrm{~m}$ & $106758 \mathrm{~m}$ & 931 \\
\hline Number of mistakes $-C$ & 326 & 9381 & 256 \\
\hline $\begin{array}{l}\text { Length of measured track without } B \\
\text { and } C \text { mistakes }-\Sigma l\end{array}$ & $42976 \mathrm{~m}$ & 7778 & $7615 \mathrm{~m}$ \\
\hline Quality of infrastructure $-K$ & 0,77 & 0,70 & 0,69 \\
\hline
\end{tabular}

Table 7 ORIE value with parameters for railway Belgrade - Mala Krsna for year 2011

\begin{tabular}{|l|c|c|c|c|c|c|c|c|}
\hline \multicolumn{9}{|c|}{ The track number 4. Belgrade - Mala Krsna } \\
\hline \multicolumn{1}{|c|}{ Month } & $U T$ & $T D I F$ & $T D O M$ & $T T O T$ & $T D N M R$ & $T D S R$ & $K$ & $O R I E / \%$ \\
\hline January & 40920 & 695 & 0 & 65934 & 3263 & 14850 & 0,77 & 58,86 \\
\hline February & 36960 & 198 & 0 & 65823 & 3595 & 14825 & 0,77 & 59,46 \\
\hline March & 40920 & 176 & 0 & 78477 & 3906 & 17675 & 0,77 & 59,79 \\
\hline April & 39600 & 154 & 66 & 76590 & 2379 & 17250 & 0,77 & 60,22 \\
\hline May & 40920 & 142 & 0 & 71151 & 2805 & 16025 & 0,77 & 60,38 \\
\hline June & 39600 & 115 & 0 & 63492 & 3675 & 14300 & 0,77 & 59,46 \\
\hline July & 40920 & 167 & 0 & 62826 & 3766 & 14150 & 0,77 & 58,70 \\
\hline August & 40920 & 134 & 0 & 55056 & 2647 & 12400 & 0,77 & 59,87 \\
\hline September & 39600 & 193 & 0 & 54723 & 2541 & 12325 & 0,77 & 59,95 \\
\hline October & 40920 & 441 & 0 & 65934 & 2393 & 14850 & 0,77 & 60,43 \\
\hline November & 39600 & 126 & 0 & 61716 & 2573 & 13900 & 0,77 & 60,17 \\
\hline December & 40920 & 97 & 0 & 67710 & 2014 & 15250 & 0,77 & 60,71 \\
\hline
\end{tabular}


Table 8 ORIE value with parameters for railway Mala Krsna - Majdanpek for year 2011

\begin{tabular}{|c|c|c|c|c|c|c|c|c|}
\hline \multicolumn{9}{|c|}{ The track number 36. Mala Krsna - Majdanpek } \\
\hline Month & $U T$ & TDIF & $T D O M$ & TTOT & $T D N M R$ & $T D S R$ & $K$ & ORIE / \% \\
\hline January & 40920 & 521 & 0 & 36566 & 6110 & 6654 & 0,70 & 51,29 \\
\hline February & 36960 & 480 & 0 & 36493 & 7018 & 5937 & 0,70 & 50,99 \\
\hline March & 40920 & 325 & 0 & 41299 & 7373 & 6751 & 0,70 & 51,75 \\
\hline April & 39600 & 95 & 0 & 39328 & 4246 & 6392 & 0,70 & 54,99 \\
\hline May & 40920 & 385 & 0 & 35908 & 5109 & 5732 & 0,70 & 53,40 \\
\hline June & 39600 & 479 & 0 & 31719 & 7211 & 4971 & 0,70 & 50,07 \\
\hline July & 40920 & 108 & 0 & 26323 & 7754 & 3967 & 0,70 & 47,95 \\
\hline August & 40920 & 128 & 0 & 20482 & 4958 & 2898 & 0,70 & 50,01 \\
\hline September & 39600 & 238 & 0 & 20847 & 6101 & 3017 & 0,70 & 48,21 \\
\hline October & 40920 & 122 & 0 & 31099 & 5135 & 4851 & 0,70 & 52,46 \\
\hline November & 39600 & 393 & 0 & 28763 & 5325 & 4487 & 0,70 & 53,76 \\
\hline December & 40920 & 192 & 293 & 25459 & 3892 & 3871 & 0,70 & 53,11 \\
\hline
\end{tabular}

Table 9 ORIE value with parameters for railway Smederevo - Mala Krsna for year 2011

\begin{tabular}{|l|c|c|c|c|c|c|c|c|}
\hline \multicolumn{9}{|c|}{ The track number 54. Smederevo - Mala Krsna } \\
\hline \multicolumn{1}{|c|}{ Month } & $U T$ & $T D I F$ & $T D O M$ & $T T O T$ & \multicolumn{1}{c|}{ TDNMR } & $T D S R$ & \multicolumn{1}{c|}{ ORIE / \% } \\
\hline January & 40920 & 934 & 0 & 25852 & 1766 & 2248 & 0,69 & 58,35 \\
\hline February & 36960 & 580 & 0 & 24702 & 2610 & 2148 & 0,69 & 54,46 \\
\hline March & 40920 & 447 & 0 & 30245 & 1991 & 2630 & 0,69 & 56,63 \\
\hline April & 39600 & 288 & 354 & 27301 & 1398 & 2374 & 0,69 & 57,06 \\
\hline May & 40920 & 493 & 0 & 26979 & 1908 & 2346 & 0,69 & 58,89 \\
\hline June & 39600 & 363 & 0 & 24472 & 2815 & 2128 & 0,69 & 56,83 \\
\hline July & 40920 & 435 & 0 & 23161 & 3749 & 2014 & 0,69 & 54,70 \\
\hline August & 40920 & 568 & 0 & 22885 & 3962 & 1990 & 0,69 & 53,99 \\
\hline September & 39600 & 305 & 0 & 22425 & 5059 & 1950 & 0,69 & 52,04 \\
\hline October & 40920 & 269 & 0 & 21482 & 5337 & 1868 & 0,69 & 51,15 \\
\hline November & 39600 & 329 & 0 & 23506 & 4064 & 2044 & 0,69 & 51,86 \\
\hline December & 40920 & 273 & 0 & 19964 & 2143 & 1736 & 0,69 & 57,20 \\
\hline
\end{tabular}

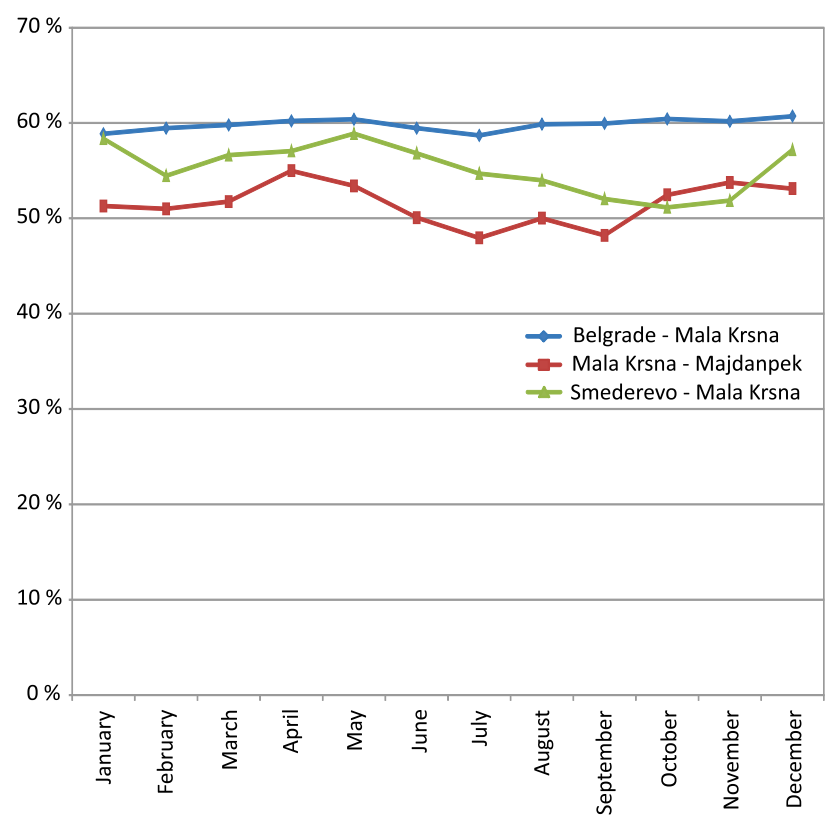

Figure 1 Comparison of ORIE values by months for three rail sections for year 2011

Calculation of monthly ORIE value for rail Belgrade - Mala Krsna is presented in Tab. 7. The table includes the following parametres: $U T$ is based on dominant traffic day; TDIF - delays due to infrastructure failure; TDOM delays due to delayed maintenance; TTOT - mean value according to timetable for year 2011; TDNMR - train delay which is not caused by maintenance and TDSR train delay due to speed decreasing (slow drives). Infrastructure quality rate $(K)$ is calculated by analysis of data obtained by recording of geometric condition of rail, using device EM 80L, [18]. The result of average value of ORIE during year 2011, railway Belgrade - Mala Krsna was $59,83 \%$. Maximum ORIE value of $60,71 \%$ was calculated in December, while minimum ORIE value of $58,86 \%$ was calculated in January, which is presented in Tab. 7.

The average result for ORIE value during 2011 for railway Mala Krsna - Majdanpek was 51,5 \%. Maximum ORIE value of $54,99 \%$ was calculated in April, while the minimum ORIE value of 47,95 \% was calculated in July, as it is shown in Tab. 8.

The average ORIE value during 2011 for railway Smederevo - Mala Krsna was 55,26 \%. Maximum ORIE value of $58,89 \%$ was calculated in May, while minimum ORIE value of $51,15 \%$ was calculated in October, as it is shown in Tab. 9. While comparing of ORIE values for three rail sections, the result varies from $47,95 \%$ to $59,83 \%$ as shown in Fig. 1.

\section{$7 \quad$ Analysis and research results}

Total effectiveness of railway infrastructure for three railway sections of Serbia Railways is in interval from $51,5 \%$ to $59,83 \%$. Ahren and Parida [3] in their research for three rail sections (Bracke - Ostersund, Jarna - Aby and Boden - Gallivare) on Swedish railways calculated ORIE values in interval from 98,0 to $100 \%$. The obvious difference in results can be noted, although it could be smaller if three sections from Serbia Railway on Coridor $\mathrm{X}$ were considered. These sections have better infrastructure quality.

Conducted analysis provided the following results: 
- Hypothesis H0 - it is confirmed that ORIE pattern can be used for monitoring of total effectivenes of railway infrastructure for Serbia Railway.

- Hypothesis H1 - it is confirmed that ORIE pattern can be used by managers of railway infrastructure. It can be used as a key perfomance indicator.

- Hypothesis $\mathrm{H} 2$ - it is confirmed that railway infrastructure managers have needs and demands for calculation of total effectiveness of railway infrastructure.

- Hypothesis H3 - it is confirmed that ORIE pattern provides important data for infrastructure managers regarding more quality in decision making processes.

ORIE concept has an aim to discover how well railway infrastructure system can deliver arranged services for traffic operators. The aim of the research was to investigate the possibility of use of ORIE pattern by managers of infrastructure for Serbia Railways, which leads to greater quality in monitoring of total effectiveness of railway infrastructure and decision making processes.

\section{Conclusion}

Research conclusion is derived according to literature review and the case study which is analyzed in this work. The analysis of obtained results provided the following conclusions:

- Presented case study showed how to use (in literature) indicators transformation and pattern for OEE in railway infrastructure, known as "overall railway infrastructure effectiveness" - (ORIE);

- It is verry little done regarding introduction of contemporary technologies for traffic management implementation of intelligent traffic systems. Possible areas include use of remote monitoring of the situation and creating of an intelligent infrastructure that can monitor and control itself.

- The use of patterns for calculation of ORIE values improves the quality of decision making by managers of railway infrastructure;

Common goals of railway transport system development include demands for better compatibility with European transport system and better transport efficiency by the use of advanced maintenance engineering.

Future researches can be directed to calculation of ORIE values for railway Corridor $\mathrm{X}$ before and after the modernization planned by business plan of "Serbian Railway" JSC.

\section{References}

[1] Liyanage, J. P.; Kumar, U. Adjusting maintenance policy to business conditions: value-based maintenance performance measurement. // Proceedings IFRIMmmm: Maintenance Management \& Modelling Conference, Växjö, 2002.

[2] Ted, S. Corridor Infrastructure Management an Emerging Approach of Using Information for Improved Railway Safety, Reliability and Profitability, Benetly System White Paper, January 11, 2008.

[3] Thomas, A.; Aditya, P. Overall railway infrastructure effectiveness (ORIE): A case study on the Swedish rail network. // Journal of Quality in Maintenance Engineering. 15, 1(2009), pp. 17-30. DOI: 10.1108/13552510910943868

[4] Ajren, Z. Life cycle cost analysis for managing rail infrastructure - Concept of a decision support system for railway design and maintenance. // European Journal of Transport and Infrastructure Research. 1, 4(2001), pp. 391413.

[5] Patra, A. P. Maintenance decision support models for railway infrastructure using RAMS \& LCC analyses. // Luleå Tekniska Universitet. (Doctoral thesis / Luleå University of Technology), Luleå, 2009, 54 p.

[6] Williamson, R. M. Strategic Work Systems, Inc.Columbus, North Carolina. // $14^{\text {th }}$ Annual Conference, SMRP 06, Oktober 22-26, Alabama, 2006.

[7] Rajman, B. Održavanje mašina sa OEE - nadzorom. // Journal of Applied Engineering Science. 4, 11(2006), pp. 714.

[8] Ahren, T. Maintenance performance indicators (MPIs) for railway infrastructure: identification and analysis for improvement. // Luleå Tekniska Universitet. (Doctoral thesis / Luleå University of Technology, No. 2008:19), Luleå, 2008, $39 \mathrm{p}$.

[9] Sektor za gređevinske poslove. Pregled kategorija pruga i brzina pri snimanju geometrije stanja koloseka mernim kolima EM-80L, broj 21/11-V-5019 od 13. Decembar 2011.

[10] Sektor za ETP, OJ za ETP Požarevac, Pregled smetnji na SS- uređajima za 2011. godinu, elektronska verzija. Decembar 2011

[11] Zajednica Jugoslovenskih Železnica, Uputstvo o jedinstvenim kriterijumima za kontrolu stanja pruga na mreži JŽ, Uputstvo 339, ŽELIND, ZJŽ 2.2, br. 92/43 2001, Beograd, 2001, pp. 7-25.

[12] Sektor za gređevinske poslove, OC ZOP Požarevac. Pregled intervencija na pruzi za 2011. godinu. Decembar 2011.

[13] OC ZOP Požarevac. Presek laganih vožnji na dan 05.05.2011.

[14] OC ZOP Požarevac. Presek laganih vožnji na dan 06.12 .2011$.

[15] OC za SP Požarevac. Grafikon 9.2 - lagane vožnje za red vožnje 2010/2011. - rasporedni odsek Beograd - Požarevac - Smederevo, 2011.

[16] OC za SP Požarevac. Grafikon 9.2 - lagane vožnje za red vožnje 2010/2011. - rasporedni odsek Požarevac - Zaječar, 2011.

[17] OC ZOP Požarevac. Pregled zatvora pruge za 2011. godinu, obrazac S - 17, 2011.

[18] OC ZOP Požarevac. Analiza podataka dobijenih snimanjem geometrijskog stanja koloseka mernim kolima EM-80L. Broj 21/11-V-1978 od 19 maja 011.godine. 2011.

\section{Authors' addresses}

\section{Ivica Nikolic, PhD student}

Engineering Sciences University of Kragujevac

Sestre Janjic 6

34000 Kragujevac, Serbia

E-mail: ivica.nikolic@fink.rs

\section{Slavko Arsovski, PhD, Full Professor}

Engineering Sciences University of Kragujevac

Sestre Janjic 6

34000 Kragujevac, Serbia

E-mail: cqm@kg.ac.rs

\section{Milan Eric, PhD, Associate Professor}

Engineering Sciences University of Kragujevac

Sestre Janjic 6

34000 Kragujevac, Serbia

E-mail: ericm@kg.ac.rs 


\section{Sladjana Vujicic, PhD student}

Faculty of Business Economics and Entrepreneurship

Mitropolita Petra 8

11000 Belgrade, Serbia

E-mail: sladjanakonto@gmail.com

\section{Goran Manojlovic, PhD student}

Engineering Sciences University of Kragujevac

Sestre Janjic 6

34000 Kragujevac, Serbia

E-mail: goran.manojlovic@fink.rs

\section{Jelena Jovanović, PhD student}

University of Montenegro, Faculty of

Mechanical Engineering,

Džordža Vašingtona bb

81000 Podgorica, Montenegro

E-mail: jelenajov@ac.me 